\title{
Income Inequality and International Economic Law: From Flint, Michigan to the Doha Round, and Back ${ }^{1}$
}

\author{
Chantal Thomas \\ Professor, Cornell Law School
}

The questions I would like to explore are:

- First, what is the scale of contemporary income inequality?

- Second, what does income inequality have to do with international law?

I am going to move between, and hopefully connect, income inequality at a domestic level, here in the US, and at the global level, so this is the reason for the subtitle, "From Flint Michigan to the Doha Round and Back."

Flint, Michigan was in the news most recently, some months ago, because of a water contamination scandal related to governmental failure, not only to ensure water quality, but also to respond to public concerns about it. But Flint also was at one time a US manufacturing powerhouse, and so the latest story about water contamination in Flint was part of a larger narrative of deindustrialization and economic decline.

The Doha Round, the other part of the subtitle, is the latest round of trade negotiations among the membership of the World Trade Organization. The Doha Round was officially launched at the WTO's Fourth Ministerial Conference in Doha, Qatar, in 2001. The Round is also known as the Doha Development Agenda, because a fundamental objective has been to improve the trading prospects of developing countries, and thereby to increase development and reduce inequality. But the Doha Round has been the longest, and according to many, the most challenged of the trade negotiation rounds, with the latest talks concluded in 2015 in Nairobi and the next ones scheduled for just a couple of months from now, in Buenos Aires. [UPDATE: The Buenos Aires talks were considered largely a disappointment.]

Is there a connection between the stalemates of Doha and the stagnation in Flint, as different endpoints in a global order in which economic inequality has increased along with international trade?

This question returns me to my starting point, which is what is the current scale of income inequality? The answer is that we are seeing a growing gap between the richest and poorest. [Slide 2, "US income inequality greater now than since 1929']

\footnotetext{
${ }^{1}$ This paper was originally delivered as the 2017 William and Patricia Kleh Lecture at Boston University Law School. My thanks to Bill and Patricia Kleh, Professor Daniela Caruso, Dean Maureen O’Rourke, and all those who made the lecture and the ensuing discussion a possibility. An earlier version of this lecture was delivered as a keynote lecture for the 2016 meeting of the International Law Association in Provo, Utah.
} 


\section{US income inequality greater now than since 1929}

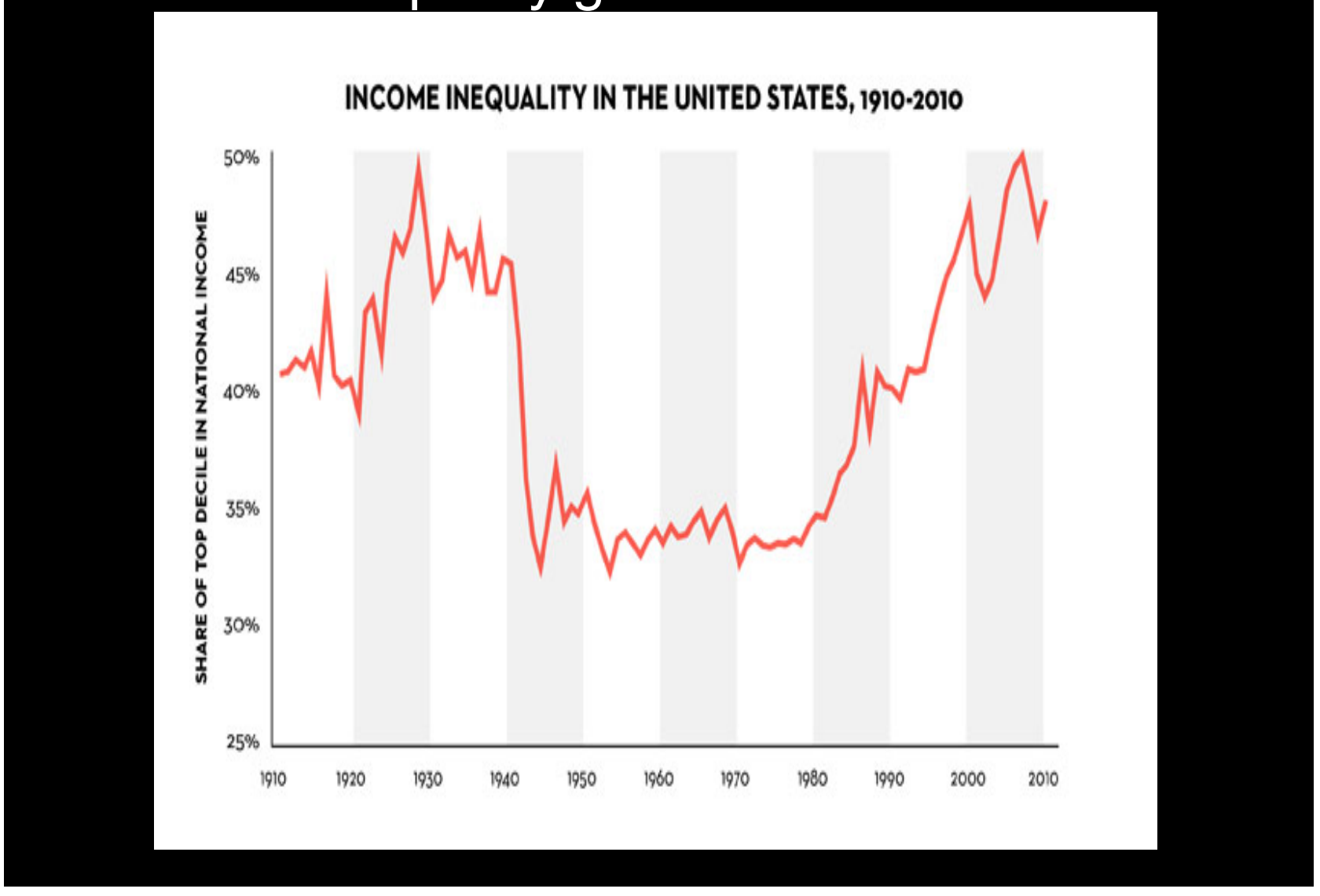

This is the slide that I previewed for those who attended our conference ("Trade Law in the Trump Era") earlier this month. It reflects the work of the economist Thomas Piketty, who in his book, Capital in the $21^{\text {st }}$ Century, showed that, in the US, economic inequality is at a higher level than at any time since late 1920s, just before the Great Depression. Piketty argues a major reason for this is that returns to capital have greatly outpaced returns to labor, and that, even within returns to labor, the gap between high and low has greatly increased.

Here are a few other indicators of this from other sources: [Slide 3, "US wage inequality increasing"] 


\section{US wage inequality increasing}

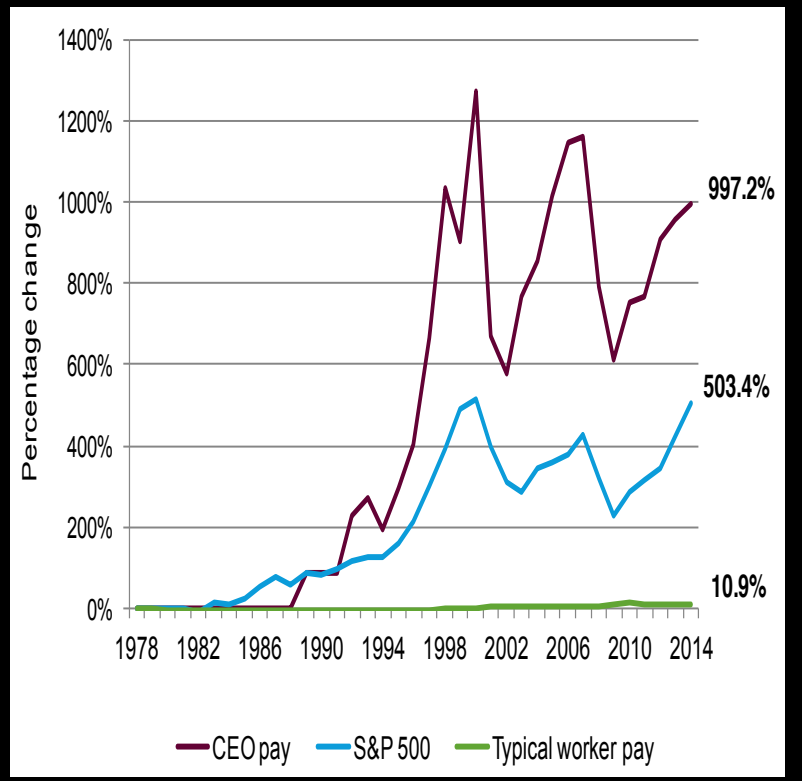

US CEO salary raises have far outstripped those of average workers (Economic Policy Institute)

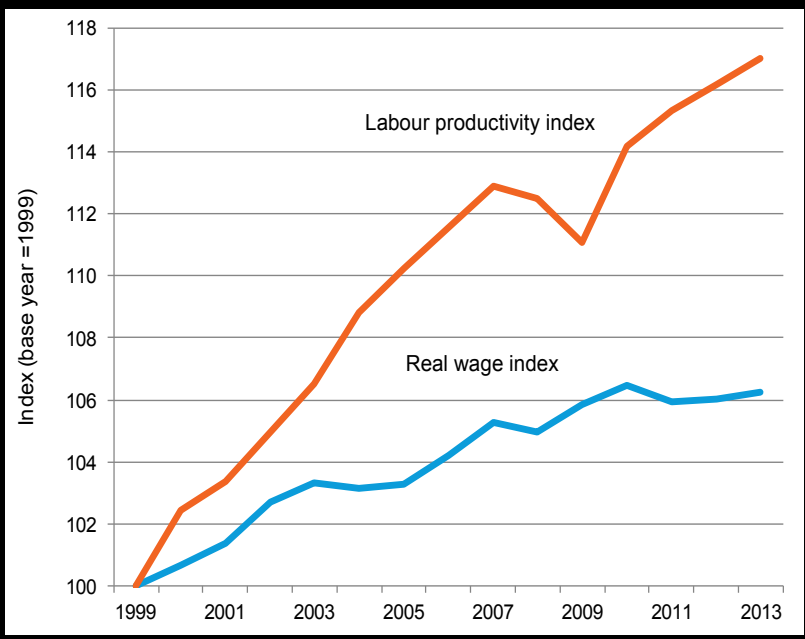

US worker productivity has increased but wages have failed to keep up (LL Global Wage Database)

The gap between executive salaries and average workers has increased, with average wages stagnating. This is the case even though worker productivity has actually increased over the same time period and so you would expect higher value added to correlate with higher wages -- but wages have failed to keep up.

And the developed world is not the only site of growing inequality. [Slide 4, "Inequality in developing countries increasing"] Piketty and his colleagues have also shown that developing countries, after a period of decreasing inequality in the early era of decolonization post World War II, have seen an increase beginning in the 1980s and 1990s. 


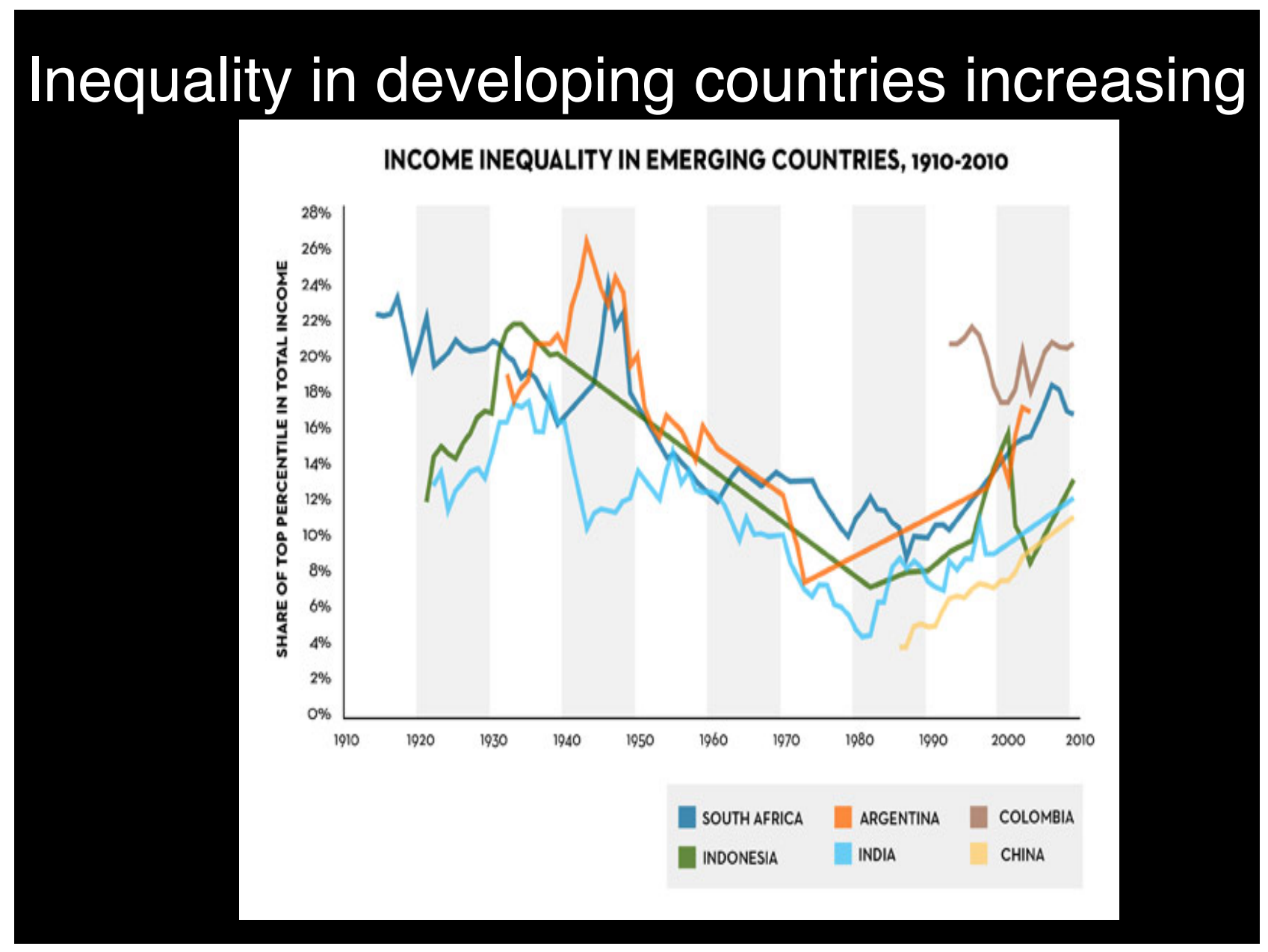

So: inequality is increasing, and it is increasing not just within individual countries but at an aggregate global level. The development organization Oxfam reported that, by the end of 2016, the richest $1 \%$ owned more than the rest of the world combined, and, that just 8 men owned more than half the world combined. ${ }^{2}$ This is not mere rhetoric, but is based on data gathered by actors in the financial world such as Credit Suisse and its Global Wealth Databook.

Oxfam's report is called "an economy for the $1 \%$." $^{3}$ The vocabulary of the $1 \%$ and the $99 \%$ is not an accident. It is the lexicon of social organizing and political protest, beginning with the Occupy Wall Street movement that emerged out of the 2008 financial crisis. [Slide 5, pictures 1-12] These terms belong to a global lexicon for social protest - and ultimately for political disruption. The political dissatisfaction reflected in this concept of the $1 \%$ fueled the Presidential campaign of Bernie Sanders, who came close to winning the Democratic presidential nomination. That same dissatisfaction course greatly propelled the campaign of the Republican candidate who ultimately won, Donald Trump. Trump ran on a platform based largely on a withering critique of the status quo in both trade and immigration policy.

\footnotetext{
2 https://www.oxfam.org/en/pressroom/pressreleases/2017-01-16/just-8-men-own-same-wealth-half-world.

3 Oxfam's 2016 Report was titled, "An Economy for the 1\%." That report stated that 62 men owned the same amount of wealth as the poorest half of the world's population (https://www.oxfam.org/sites/www.oxfam.org/files/file_attachments/bp210economy-one-percent-tax-havens-180116-en_0.pdf). The 2017 report, entitled "An Economy for the 99\%," updated that estimate to assert that only 8 men owned wealth equivalent to "the bottom half of humanity."
} 


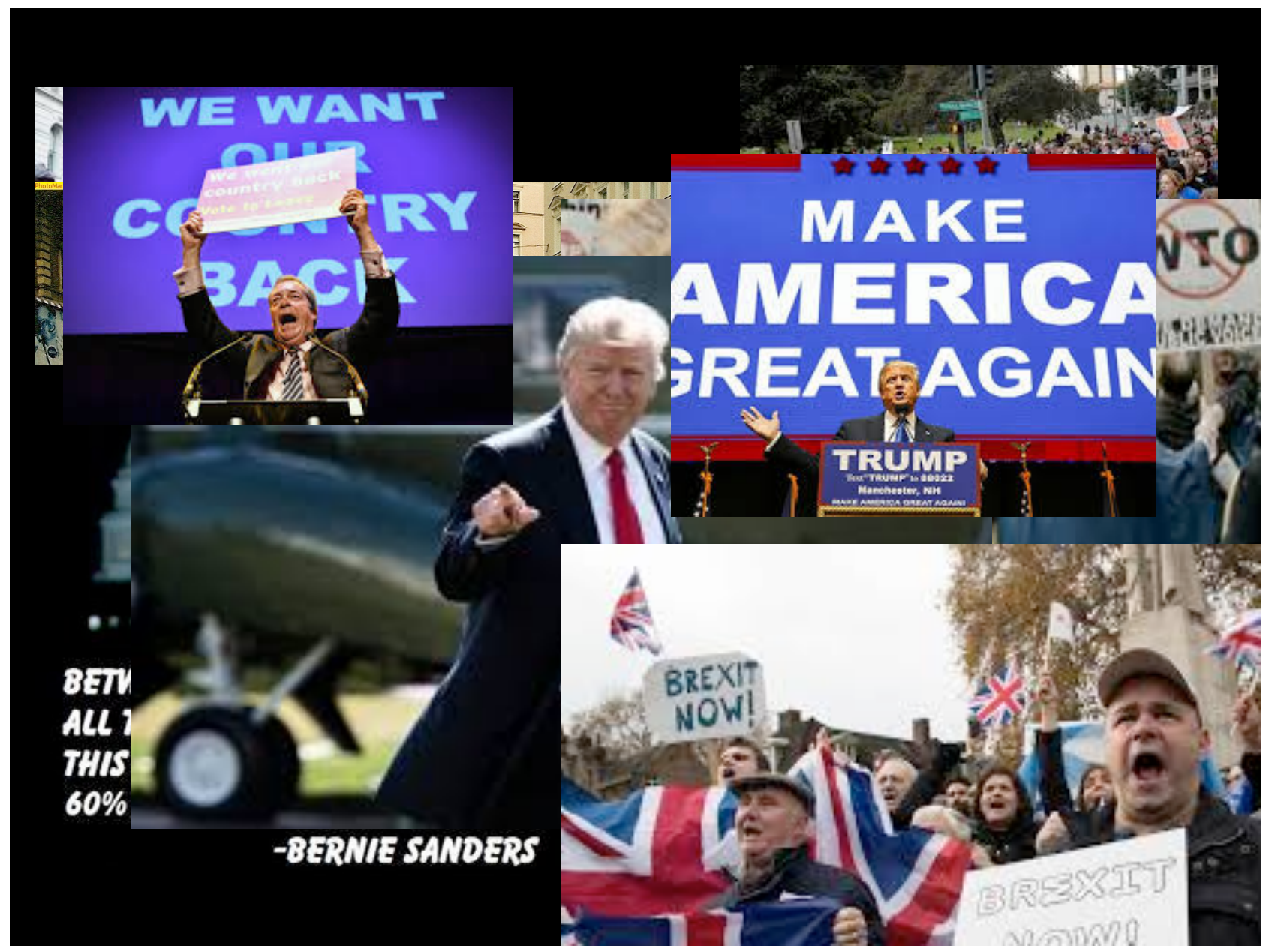

A crucial win for Trump as the electoral votes were being tallied, on the night of November $8^{\text {th }}$, 2016, was Michigan, which gave its vote to Trump on the basis of his position against international trade. That platform of isolationism was reflected in politics elsewhere as well, such as the surprise upset victory of the Brexit vote in the UK last summer (2016), where a majority of referendum voters chose to leave the European Union. And even yesterday in Germany (Sept 24, 2017), although Chancellor Merkel was returned to office, the far right won seats in the national parliament in Germany for the first time in half a century, in part based on a critique of growing inequality.

So: income inequality is real, and it is driving, in part, political dissatisfaction and unrest. But what does any of that have to do with international law? Certainly in the eyes of political and civil society groups, there is a connection. There have been a wide variety of organized protests against globalization along this same period - often taking the form of protest against various international organizations. The Montreal protest against the G20, the Prague protest against the IMF, and the infamous Battle in Seattle against the WTO were all examples of what became known as the "anti-globalization" movement, charging that the international laws overseeing global economic integration were responsible for a range of ills, from environmental destruction to global poverty.

In addition to that more familiar "anti-globalization" movement on the political left, more recently, on the political right, we also hear critiques of "globalism." This term of preference on the right, "globalism," as the NY Times reported last year (2016), "conjures many images, none of them good: shuttered factories, unchecked immigration and a distant cabal that, ... controls the economy and the media. Analysts who track extremist groups in the United States have expressed alarm at the use of the 
word by the [current president]. They say it carries multiple meanings — from benign to sinister — and often serves as a 'dog whistle' for racist, anti-Semitic and antigovernment conspiracy theorists." 4

So: we are living in a time of inflamed rhetoric against the global as a source of economic ill. But again, is there a basis to these claims? It is indisputable that over this same period of time, global trade has increased, and that that increase stems in significant part from international trade law. [Slide 6, "Ratio of global trade to global GDP has increased."] International trade has grown much faster than the rest of global economic output. [Slide 7, "International trade law has reduced trade barriers"] In part this has occurred through economic liberalization brought about by organizations like the WTO, under which trade barriers have fallen dramatically. As one example, tariffs on imported goods have come down, over the last decades, as this slide shows, to where the average tariff for developed countries is now under $5 \%--$ that is to say, trivial as an import barrier.

\section{Ratio of global trade to global GDP has increased}

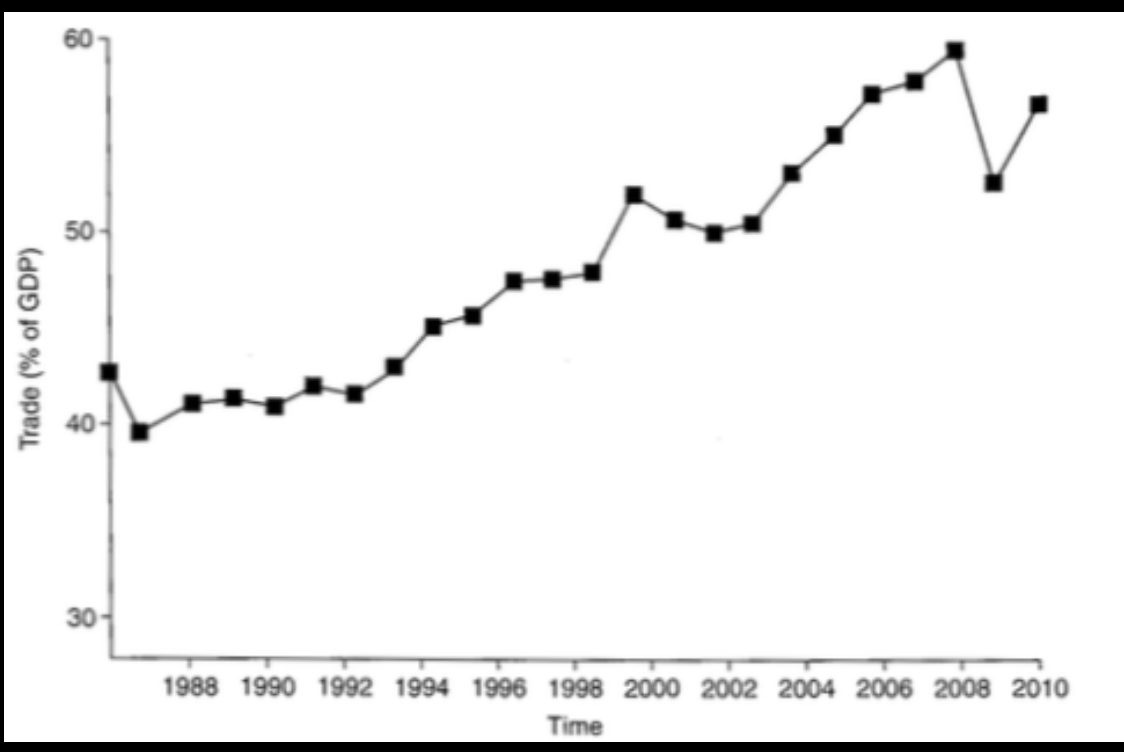

P. Van Den Bossche, The Law and Policy of the World Trade Organization (2013)

\footnotetext{
${ }^{4}$ https://www.nytimes.com/2016/11/15/us/politics/globalism-right-trump.html?mcubz=1\&_r=0
} 


\section{International trade law has reduced trade barriers}

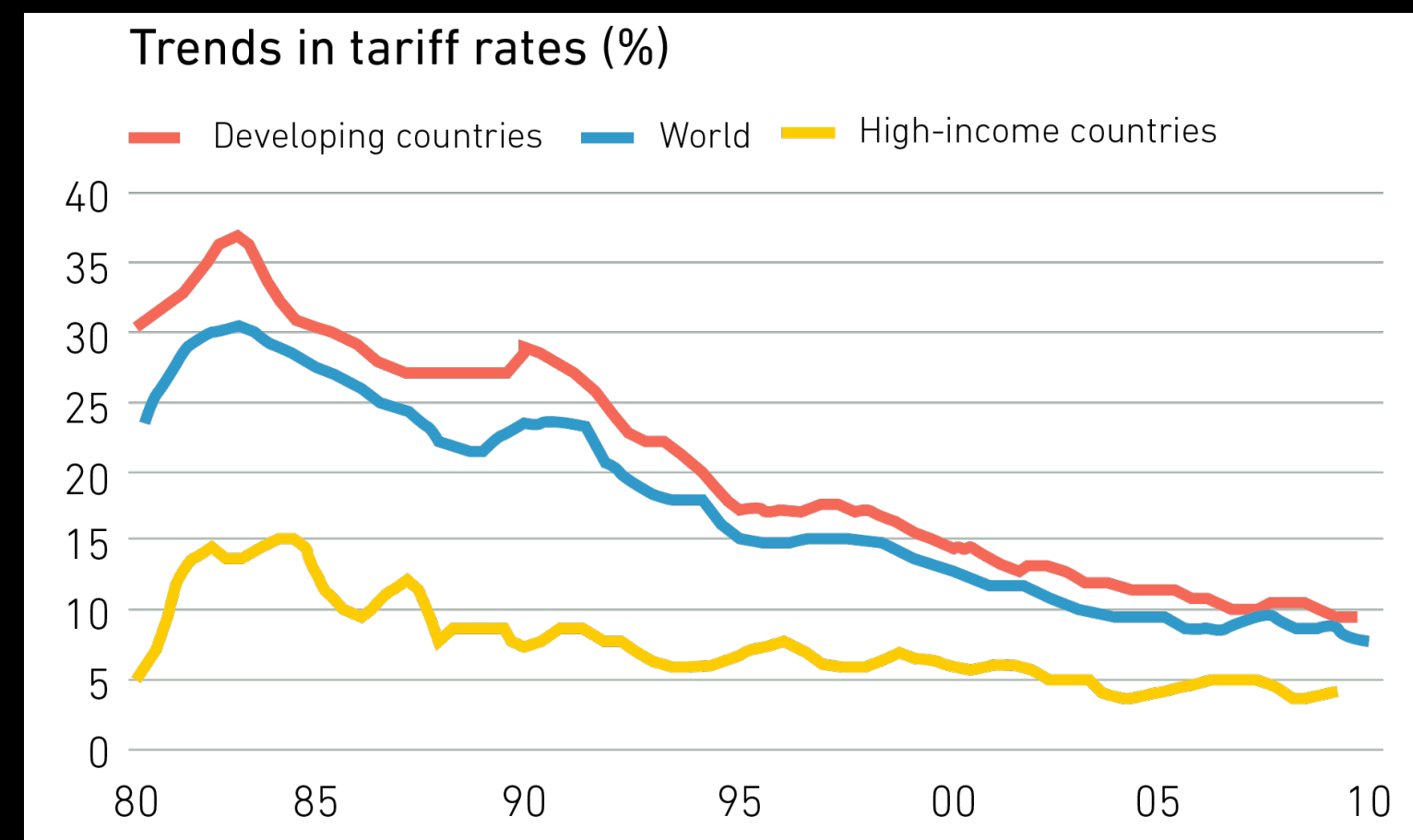

World Bank, World Development Indicators

So: globalization is real and in particular the liberalization and expansion of international trade, is real, but is globalization to blame for inequality? The case for the global economy as it is currently configured points out that, thanks to more open trade, many emerging economies have been able to reduce their poverty levels, and to close the gap with developed countries. [Slide 8, "Global poverty has declined"] The UN has reported that, globally, the number of people living in extreme poverty [[the equivalent purchasing power in the US of] \$1.25 a day] has declined by more than half over the past 25 years, essentially the period of most rapid globalization. 


\section{Global poverty has declined}

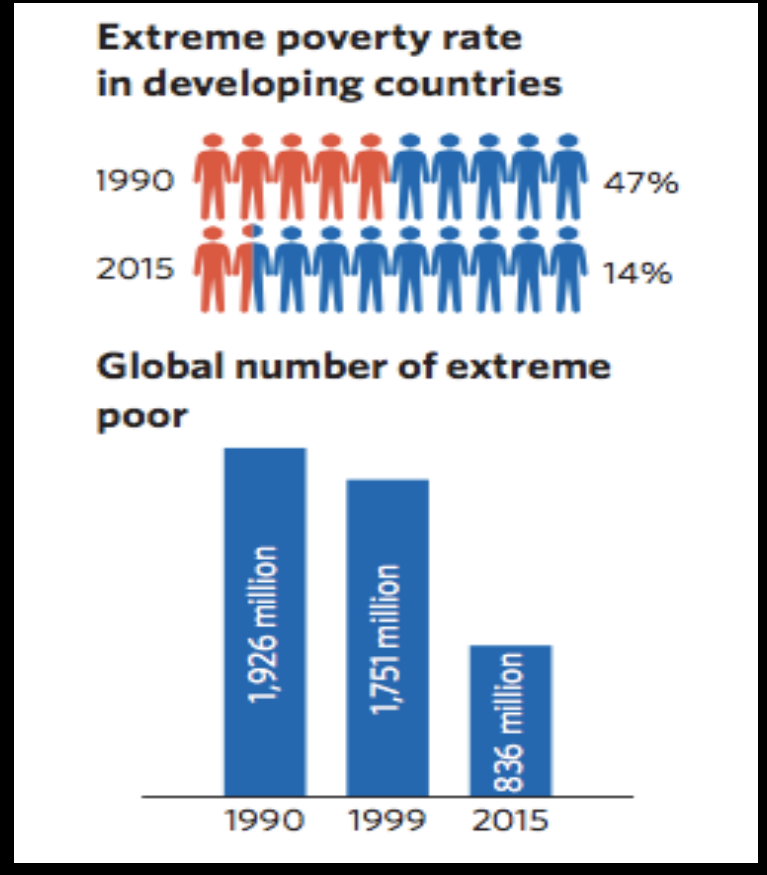

- In 1990, nearly half of

the population in the

developing world lived

on less than $\$ 1.25$ a

day; that proportion

dropped to 14 per cent

in 2015.

- Globally, the number

of people living in

extreme poverty has

declined by more than

half, falling from 1.9

billion in 1990 to 836

million in 2015.

United Nations, The Millennium Development Goals Report (2015)

Looking at that figure, one could extrapolate that perhaps we needn't be as concerned with income inequality as a product of international trade law. If global trade is lifting all boats, but some boats are going up faster than others, isn't this okay (even if some boats are rowboats and others are yachts)? The argument here would be that inequality is occurring because the incomes of the $1 \%$ or the $0.1 \%$ are increasing more rapidly than everyone else's, but everyone else's are also increasing, and amongst the poor that change turns out to be very significant even if small by comparison to the gains enjoyed by those at the top of the income spectrum.

This is what economists call a Pareto-optimal outcome: If everyone is at least a little better off, and no one is worse off, then that is one measure of a good policy - and by that measure, if that is the case for policies of globalization and economic integration, then those policies are good even though they are producing income inequality, because they are making everyone's incomes at least a little better off.

But I think we should care about inequality, even if everyone's incomes are at least a little better off (and I'll come back to this point), if some are so much better off than others. For several reasons, and I'll name just a few. First, the victories of the globalized economy, such as poverty reduction, are not themselves evenly distributed, but they reflect an internal unevenness. [Slide 9, "Poverty reduction has been uneven'] Most of the poverty reduction has occurred in East Asia - mostly accounted for by China, where literally hundreds of millions of people have emerged from poverty, and much of that has happened through trade. There are more modest but also measurable gains in India / South Asia. 


\section{Poverty reduction has been uneven}

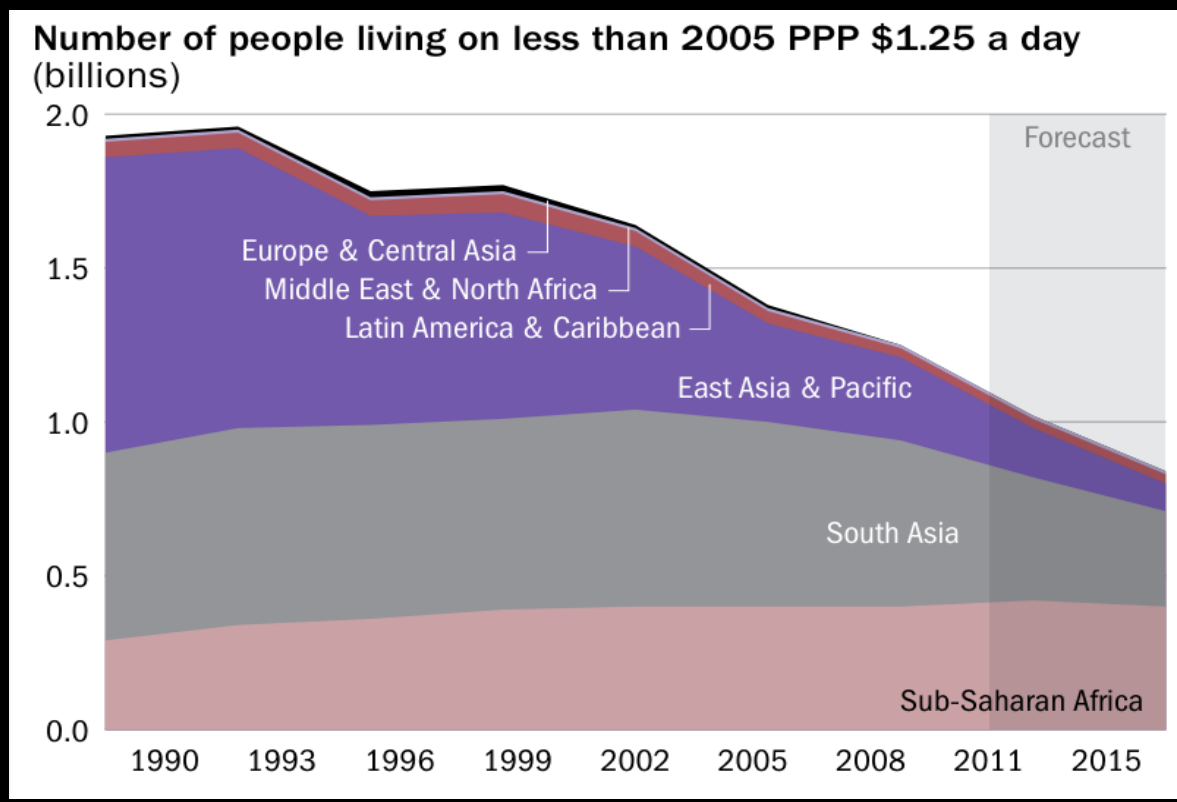

World Bank, PovCal Net

These are such large numbers that they affect the aggregate picture. And these gains are of course incredibly significant and should be celebrated as a tremendous victory over poverty. At the same time, the very poorest in the global economy are barely holding steady - looking at sub-Saharan Africa, for example, barely any of the gains in global poverty reduction have been there. [UPDATE: This is the case even though cyclical commodity price hikes in the mid-to-late 2000s produced strong growth in many African economies, leading the World Bank to publish a 2016 Report entitled, "Poverty Reduction in a Rising Africa."] The huge gains in poverty reduction in a few regions and a few countries have created an aggregate picture that belies an underlying reality in which that effect has proven to be relatively geographically concentrated.

So: one problem with the current arc of global poverty reduction is that it is unevenly distributed and many of the very poor have not seen improvement. Of course we also have to go beyond the numerical measure of income alone, and think about the social conditions that these disparities indicate. [Slide 10, "Poverty tracks other social indicators"] Disparities in poverty reduction also indicate disparities in health, in mortality, in access to water and sanitation - and sub-Saharan Africa disproportionately suffers on all those accounts. 


\section{Poverty tracks other social indicators}

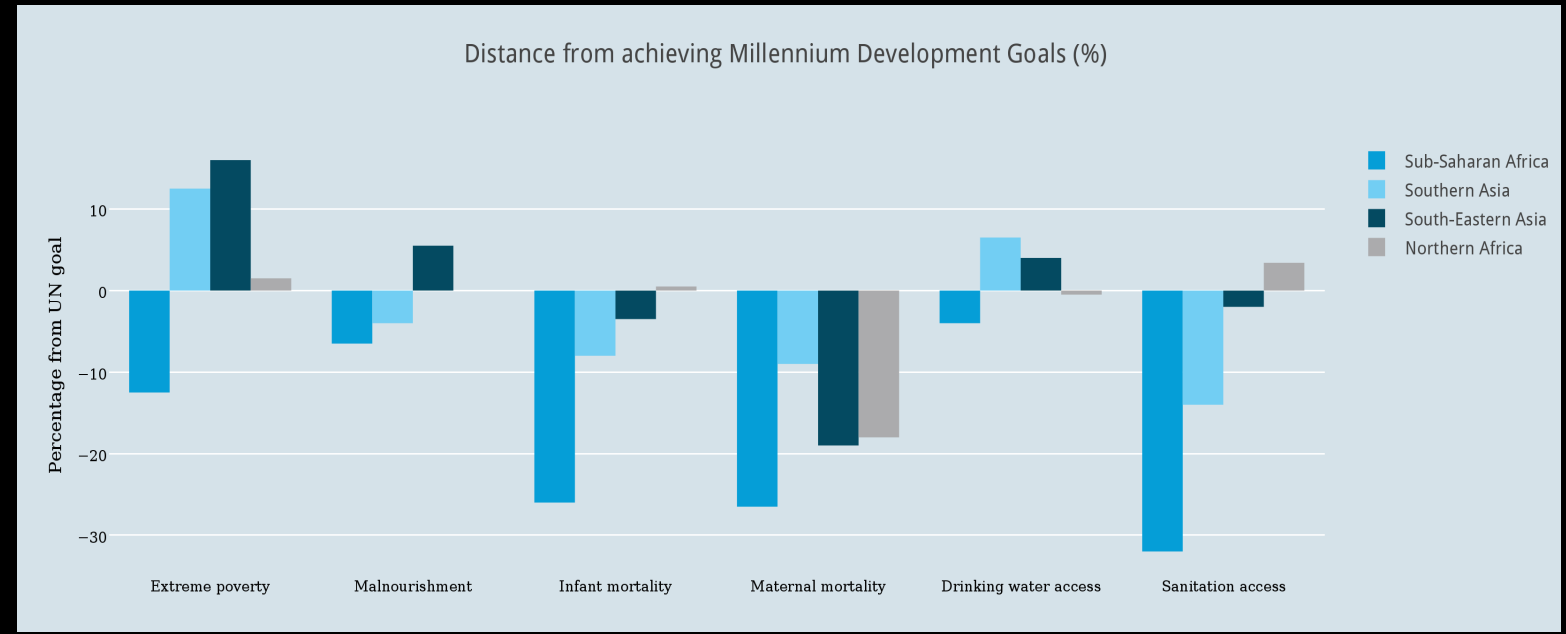

Integrated Regional Information Networks, Millennium Development Goals: An Uneven Success (2015)

The gains currently accruing to the $1 \%$ in the global economy could have gone not only to other individuals in the form of redistributed wealth, but also to general public and state functionalities - like health, education, and sanitation. Poverty at the individual level is reflected in public underinvestment at the social level. One of these areas of social investment is infrastructure. [Slide 11, "The infrastructure gap"] This image is from an article in the Economist, which reported that "global spending on basic infrastructure-transport, power, water and communications-currently amounts to about $\$ 1$ trillion a year less than it should -- $\$ 2.7$ trillion a year when it ought to be $\$ 3.7$ trillion." 


\section{The infrastructure gap}

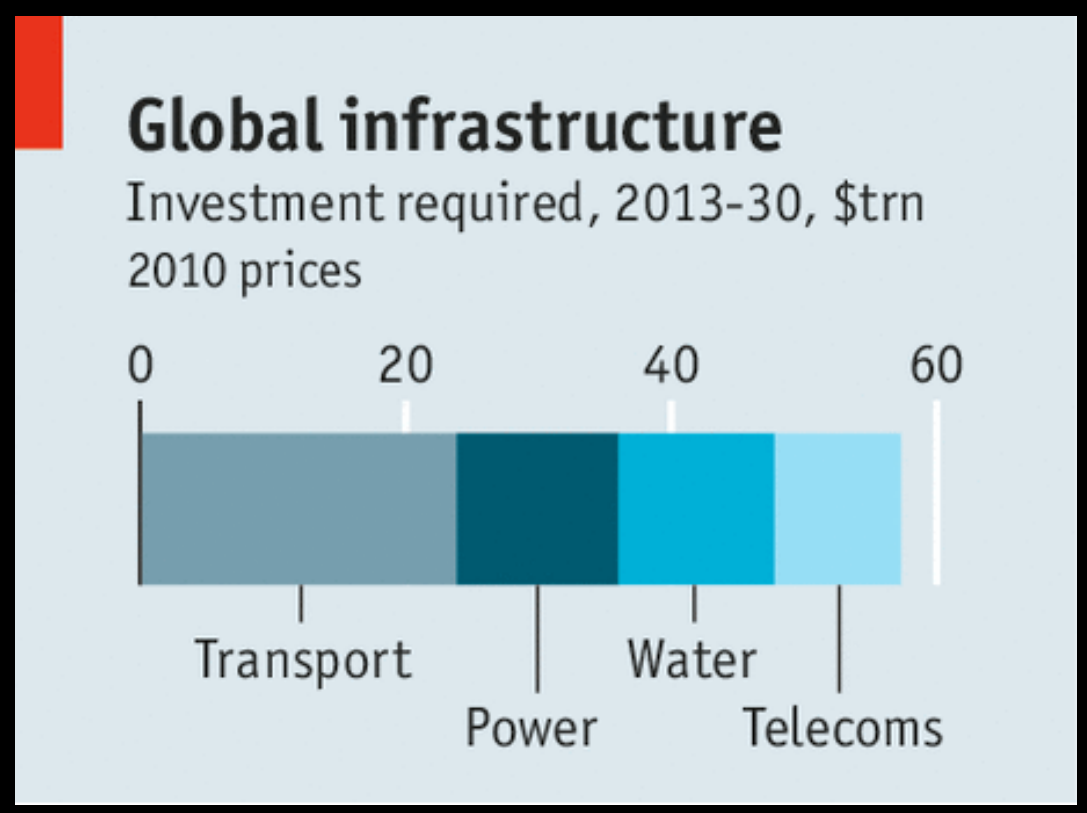

The Economist, The Trillion Dollar Gap (2014)

Concomitantly with the rise in income inequality, we have seen an underinvestment in infrastructure. This has occurred not only through lesser investment in health and education, water and sanitation infrastructure in sub-Saharan Africa, but also in the US - to return to Flint. [Slide 12, "The corrosion of infrastructure"] Water contamination was the result of a failure of infrastructural investment. The authorities adopted cost-cutting measures in changing the water supply, and then opted for less expensive and less effective techniques of controlling corrosion and contamination. 


\section{The corrosion of infrastructure}

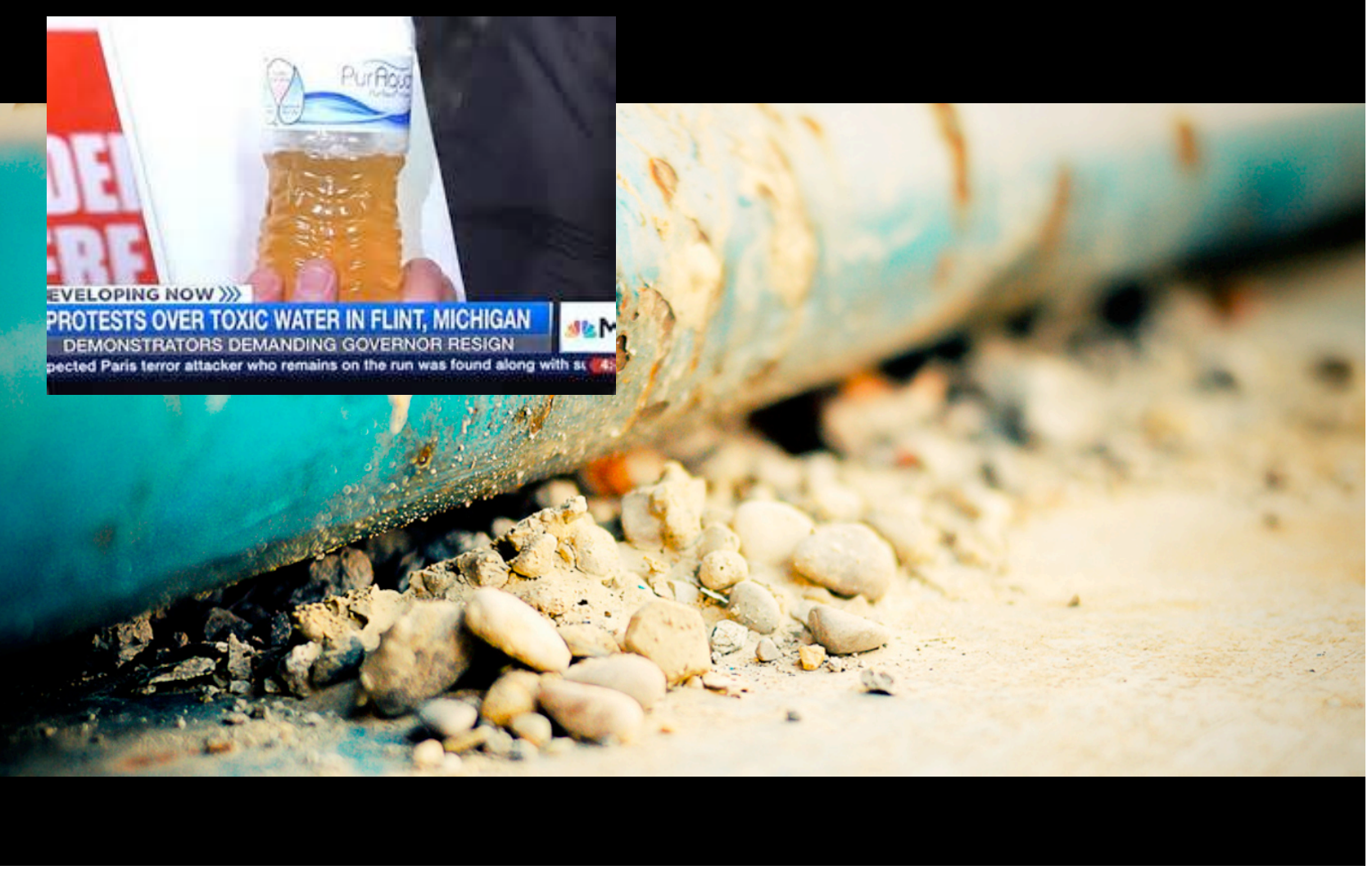

To sum up so far: we should be concerned about inequality as a separate measure, because dramatic disparities in the rates of economic gain signal a host of other social problems that jeopardize national and global wellbeing.

But that's not the end of the analysis. So far we're working on the premise that the problem with the global economy is that, even though all incomes are going up, but some are going up more quickly than others. But that turns out not to be entirely true. According to an influential depiction of global inequality by the economist Branko Milanovic, the famous "elephant graph" [Slide 13, "Winners and losers in the current global economy'] we see, as we have noted so far, that over the past three decades: income growth has been dramatic in roughly the middle $60 \%$ of the global income distribution, in the emerging economies especially China; the very poorest - including those in the least developed countries many of which are in sub-Saharan Africa - have not shared in that growth; and the global elite have done very well. The middle classes in the developed world are the only group according to Milanovic's data to experience not only flat income growth but actually negative income growth. 


\section{Winners and losers in the current global economy}

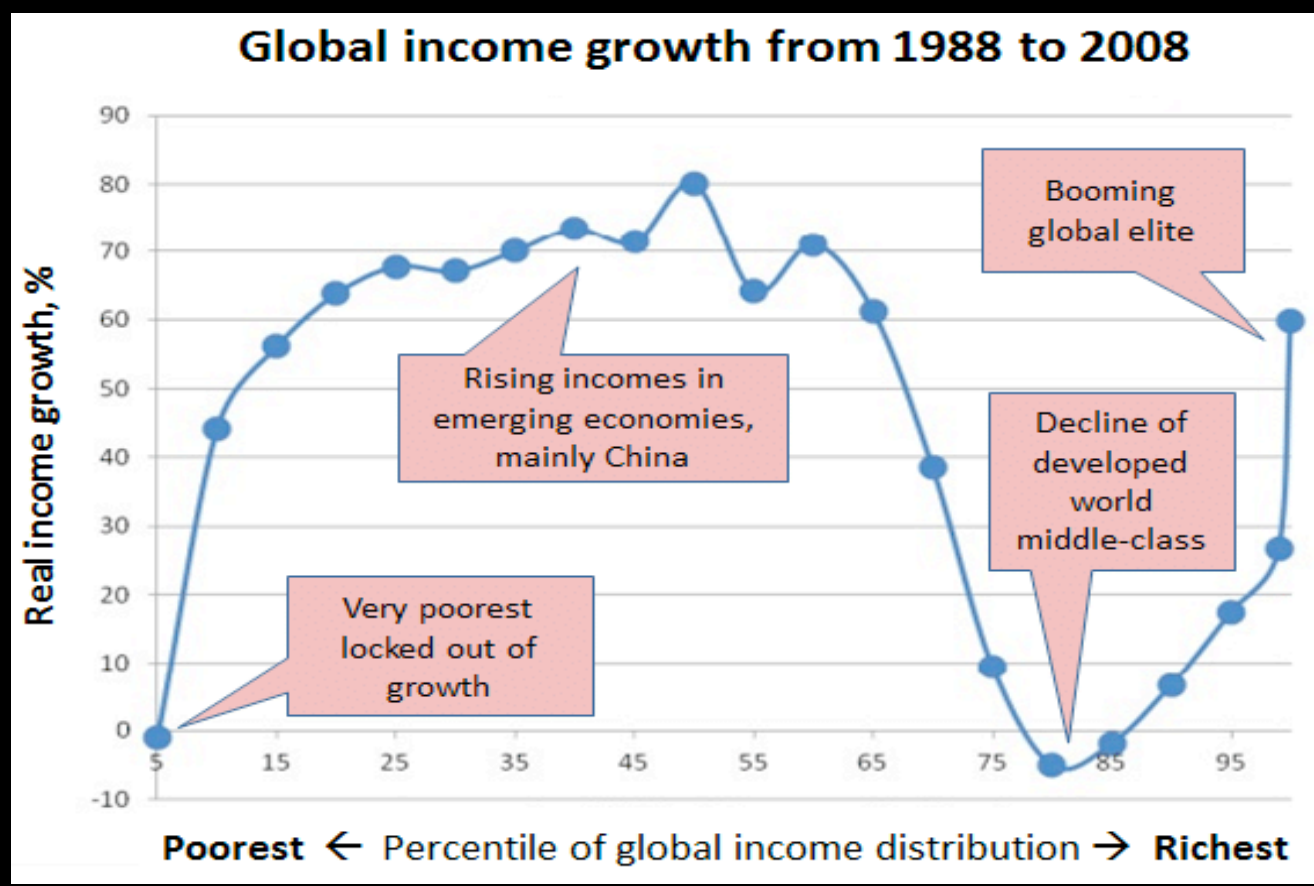

Branko Milanovic \& Christoph Lakner, Global Income Distribution (2016)

It is really no surprise, then, that the populations of the global North - the majority of whom are these very same middle classes and who have been the hardest hit in relative terms - have reacted in some cases quite furiously to the globalization model.

To return to the question of the role of international law - again, what does this have to do with international law, and international economic law in particular? With the rest of my time, I will take these two segments of the population distribution in Milanovic's global income graph that have not fared well, in turn: The world's poorest in developing countries - Doha - and the middle classes of the developed world - Flint.

We saw earlier that global trade has increased and that has brought with it significant gains for some, and the increase in global trade stems in part from international law like trade liberalization through the WTO. So, perhaps we could say, on a global level, that those economies that have done well at least in the aggregate have been more open to trade. Returning to the very poorest in the graph - to the issues represented in Doha, and I will come back to Flint - perhaps the reason for the unevenness in poverty reduction between China and sub-Saharan Africa has to do with China's greater participation in the global marketplace and its greater orientation to global trade.

But it is important to understand that is not the case. This chart indicates the opposite: if anything least developed countries (LDCs) and African countries have been greater participants in trade. [Slide 14, "Participation in global trade does not correlate with poverty reduction"] It turns out that being a winner rather than loser in global trade doesn't necessarily reflect an economy's level of trade openness, as much 
as what kind of trade it is doing. In general, it is much less profitable to be primarily an exporter of agricultural products, than manufactures, and Africa exports mostly agriculture whereas China exports mostly manufactures.

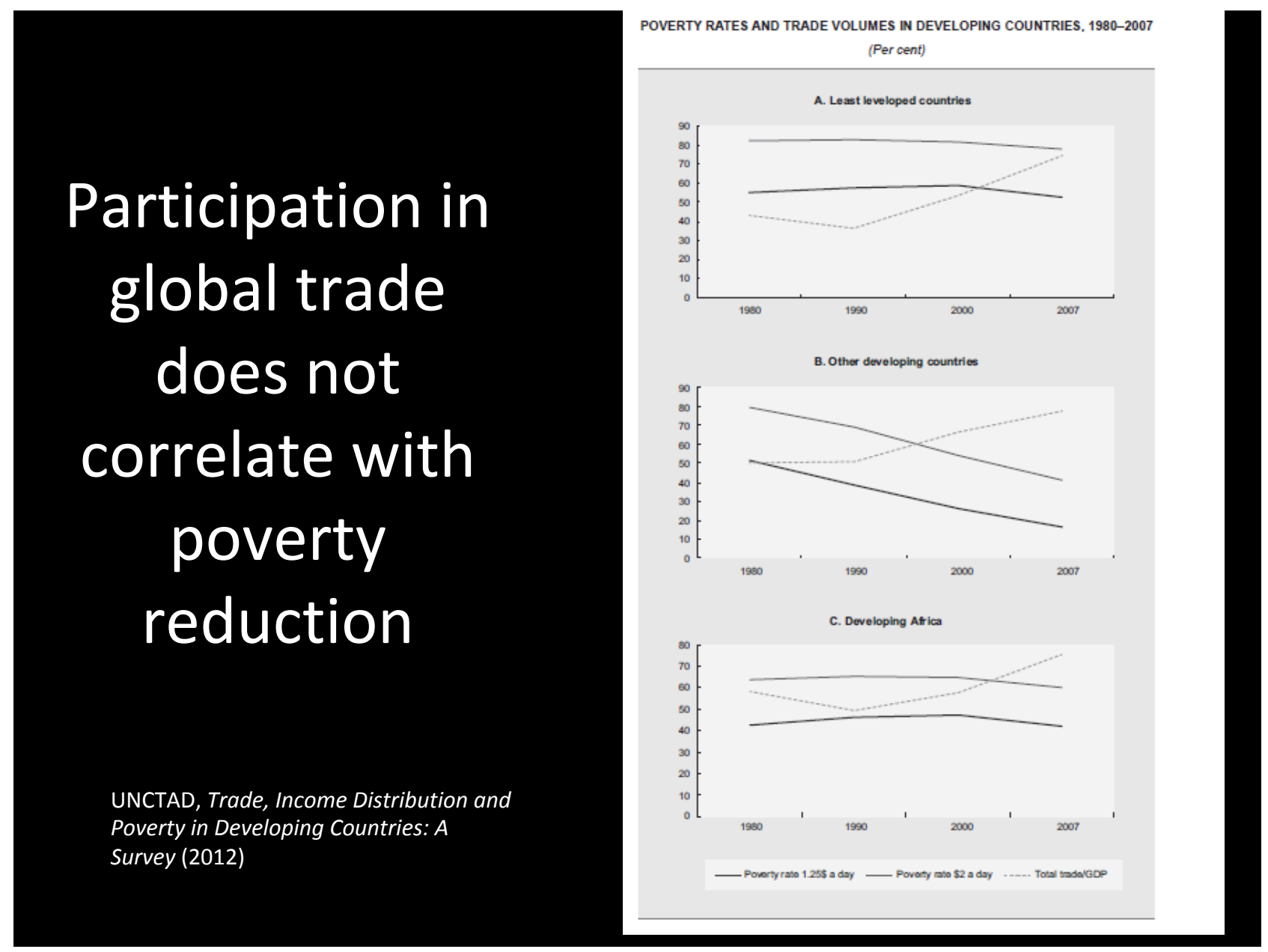

Some of this has to do with underlying economic characteristics of agricultural trade. But it is also a question of policy \& international law. There are double standards in rules on trade when it comes to agriculture - there has been much less liberalization here than in other areas of trade. [Slide 15, "International trade rules on agriculture have indicated a double standard"] Agricultural tariffs are much higher in general. Tariffs on agricultural products also feature "tariff escalation" that make it harder for countries producing agriculture to move into processing and manufacturing capacities. Rich countries maintain substantial subsidies on agriculture that have a direct impact on the livelihoods of producers in poor countries. 


\section{International trade rules on agriculture have indicated a double standard}
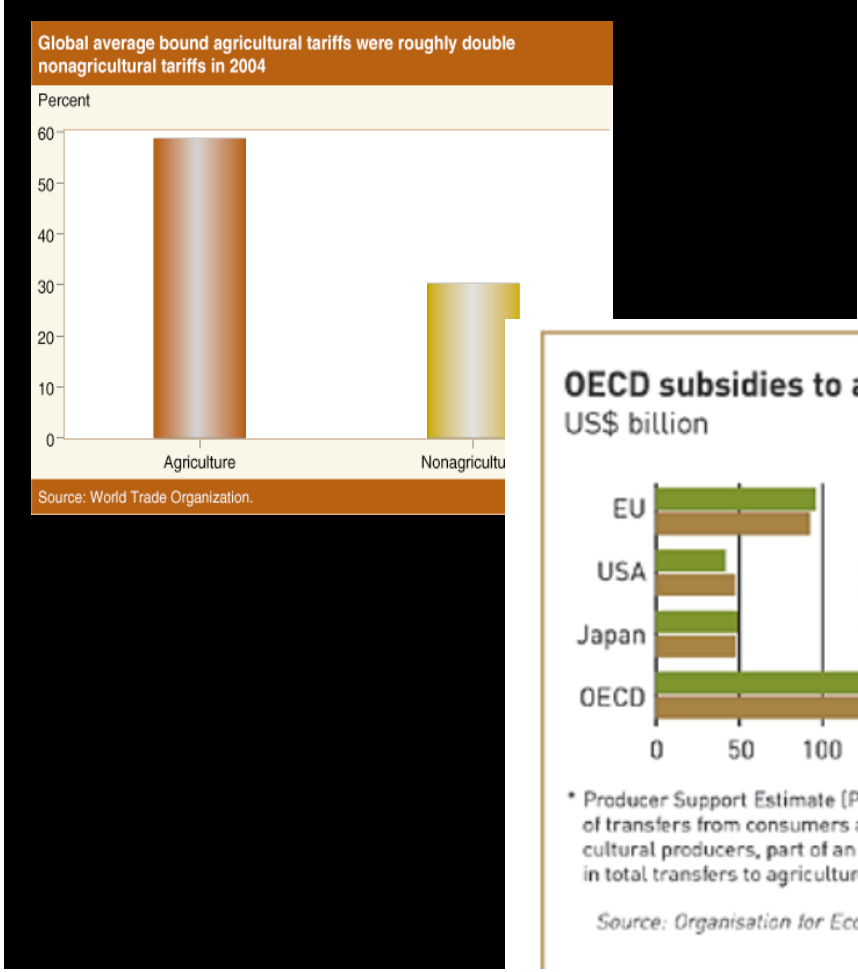

Tariff escalation in food products

OECD subsidies to agriculture* US\$ billion

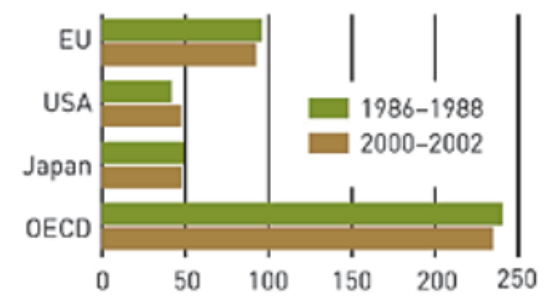

- Producer Support Estimate [PSE]: the annual value of transfers from consumers and taxpayers to agricultural producers, part of an estimated US $\$ 315$ billion in total transfers to agriculture in OECD countries.

Source: Organisation for Economic Co-operation and Development (OECD\})

Taking cotton as an extreme example that became prominent in the Doha negotiations, the US remains the world's largest exporter of cotton despite a cost of production that is at least twice that of, for example, West and Central African cotton-exporting countries. For this reason, those countries, which came to be known as the Cotton 4 in the negotiations, called for specific remedial steps to rebalance the global cotton market in the Doha round. [Slide 16, "with some extreme cases, such as the "Cotton 4" West and Central African countries"] 


\section{with some extreme cases, such as the "Cotton 4" West and Central African countries}

\begin{tabular}{|l|l|l|}
\hline \multicolumn{1}{|c|}{$\begin{array}{c}\text { Cotton } \\
\text { Exports }\end{array}$} & $\begin{array}{l}\text { United } \\
\text { States }\end{array}$ & $\begin{array}{l}\text { West and } \\
\text { Central } \\
\text { Africa }\end{array}$ \\
\hline \% of GDP & $0.034 \%$ & $5-10 \%$ \\
\hline $\begin{array}{l}\text { Cost of } \\
\text { production }\end{array}$ & $\begin{array}{l}68 \text { cents/ } \\
\text { pound }\end{array}$ & $\begin{array}{l}31 \text { cents/ } \\
\text { pound }\end{array}$ \\
\hline
\end{tabular}

Congressional Research Service, The African Cotton Initiative and WTO Agriculture Negotiations (2004)

What these observations reveal is that international trade law has contributed to a ghettoization of sorts of the poorest countries. These issues have been on the table in the Doha talks - and have been the reason why the talks have taken so long. Progress has been slow, particularly in agricultural negotiations, and a big part of the reason is that developed countries have been unwilling to move on agriculture. [Slide 17, "The World Trade Organization negotiations on the "Doha Development Agenda" had not delivered strong results...] 


\section{The World Trade Organization negotiations on the "Doha Development Agenda" had not delivered strong results...}
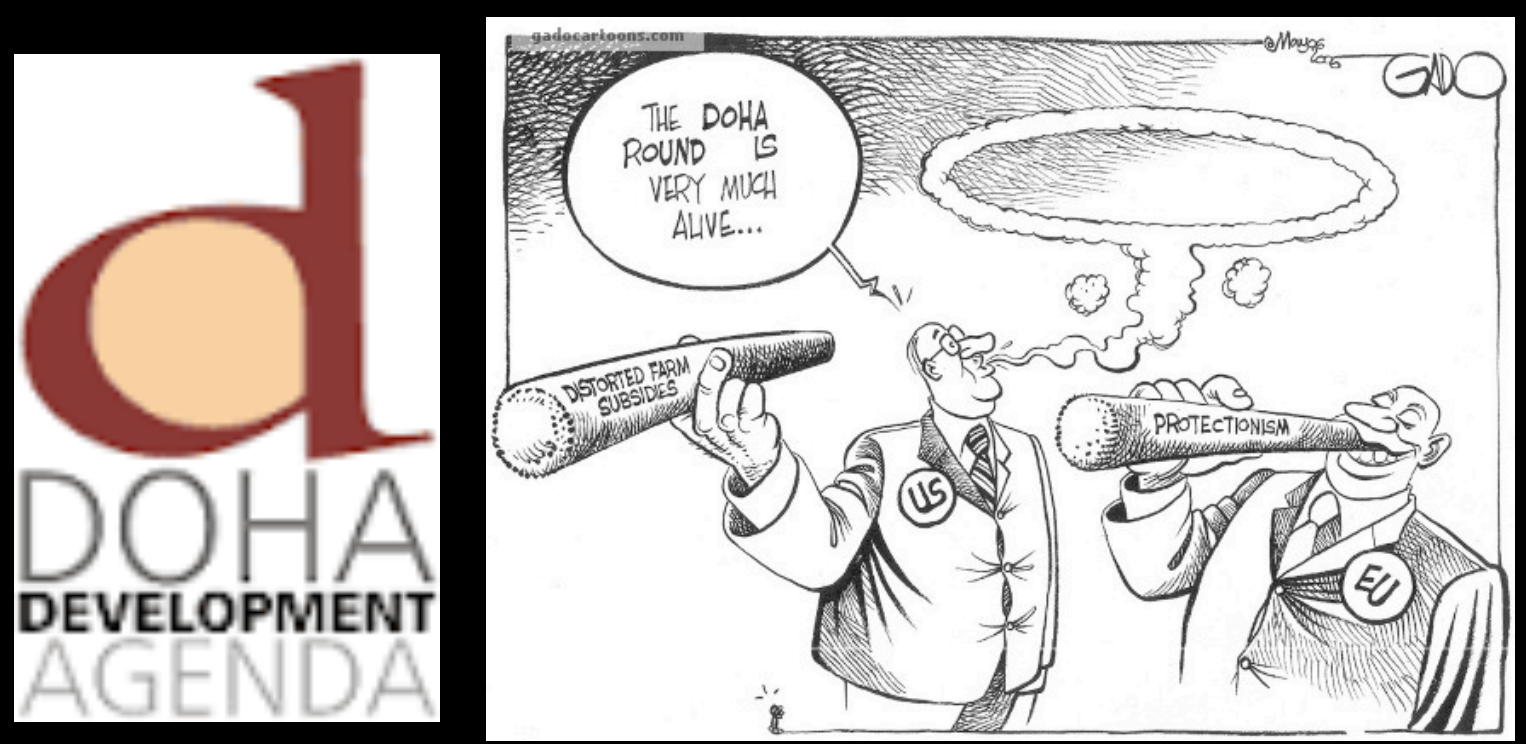

But the situation is also always open to change. And the last set of talks in Nairobi signaled a shift, and some hope. [Slide 18, "but the latest talks in Nairobi signaled modest progress"] The issue with the gains so far in the talks, including the Nairobi decisions on market access and export subsidies, is that the largest limitation on trade comes not from export subsidies or border measures like quotas or duties, but rather from domestic subsidies. A World Bank study projected that eight-ninths of the global gain in agricultural trade liberalization would have come from cutting domestic subsidies, and those cuts have not yet occurred. ${ }^{5}$

${ }^{5}$ Kym Anderson \& Ernesto Valenzuela, The World Trade Organization's Doha Cotton Initiative: A Tale of Two Issues (World Bank Development Policy Research, Working Paper No. 3918, 2006 Group). 


\section{but the latest talks in Nairobi signaled modest progress}

- Decisions of the WTO Tenth Ministerial Conference, December 2016 included:

- Duty free and quota free access for cotton from the West and Central African countries

- End to agricultural export subsidies, including cotton export subsidies (but little progress on domestic subsidies)

- Upcoming talks in Buenos Aires will focus on domestic subsidies

The Buenos Aires talks are coming up, and there is hope that domestic subsidies will be addressed directly. [UPDATE: The Buenos Aires talks were considered largely a disappointment.] In the meantime, we can conclude that international trade legal rules have helped to shape the terms of the global marketplace in which agricultural producers, including the cotton-producing West and Central African countries, and many developing countries more generally, have found it difficult to thrive.

The story of agriculture is just one of many stories one could tell in international trade law, both within the WTO and beyond - intellectual property and access to medicines , dispute settlement, and outside of the WTO regional trade agreements and bilateral investment treaties - where economic inequality reflected in and to some degree perpetuated by rules and institutions. I have no time to go into all of this but we can draw the conclusion that international economic law has contributed to the global economic inequality we saw on the graph and to locking the very poorest countries out of economic growth, but it can also change - and hopefully it will.

That is one view on Doha -- but what about Flint and the story of deindustrialization? What about the relative decline of the middle classes in the developed world? [Slide 19, "Winners and losers in the current global economy'] Is globalization, and the legal rules that have helped to create it, responsible? 


\section{Winners and losers in the current global economy}

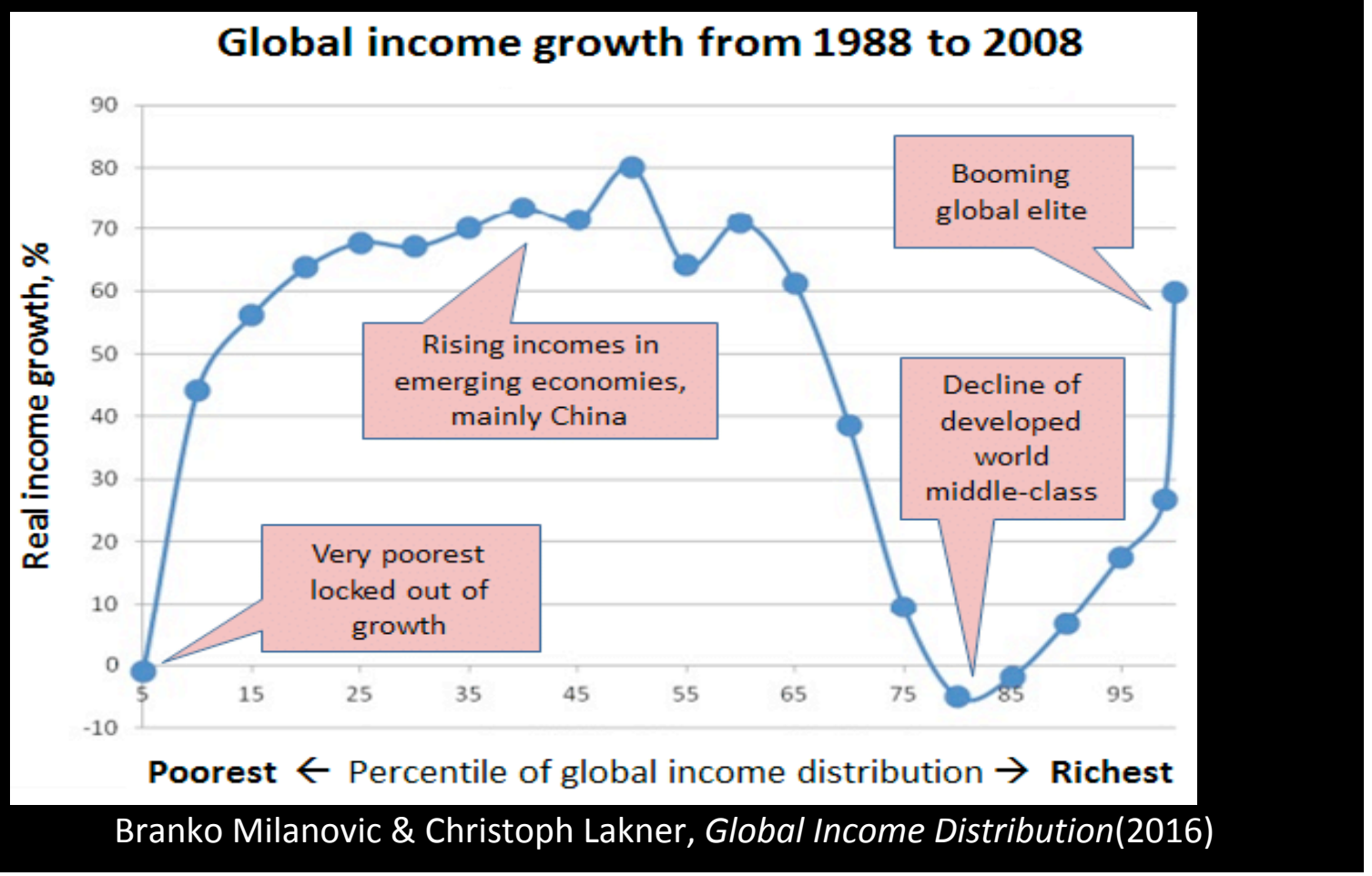

If the story of Africa shows us that trade openness is not necessarily the solution or a guarantee of economic growth, should we say that trade openness is the problem?

Let's go back to Flint. The prevailing rhetoric in the last political campaign was that NAFTA was blamed as the culprit. Are NAFTA and international trade to blame for the crisis in Flint?

[Slide 20, "U.S. Trade with NAFTA Partners"] It is clear that NAFTA has correlated with a very large increase in cross-border trade amongst the NAFTA countries - and that as far as the US is concerned, the volume of imports has been increasing more than the volume of exports - the US trade deficit with NAFTA trading partners has increased over the life of the agreement. 
Figure I.U.S.Trade with NAFTA Partners: 1993-2012

(billions of nominal U.S. dollars)

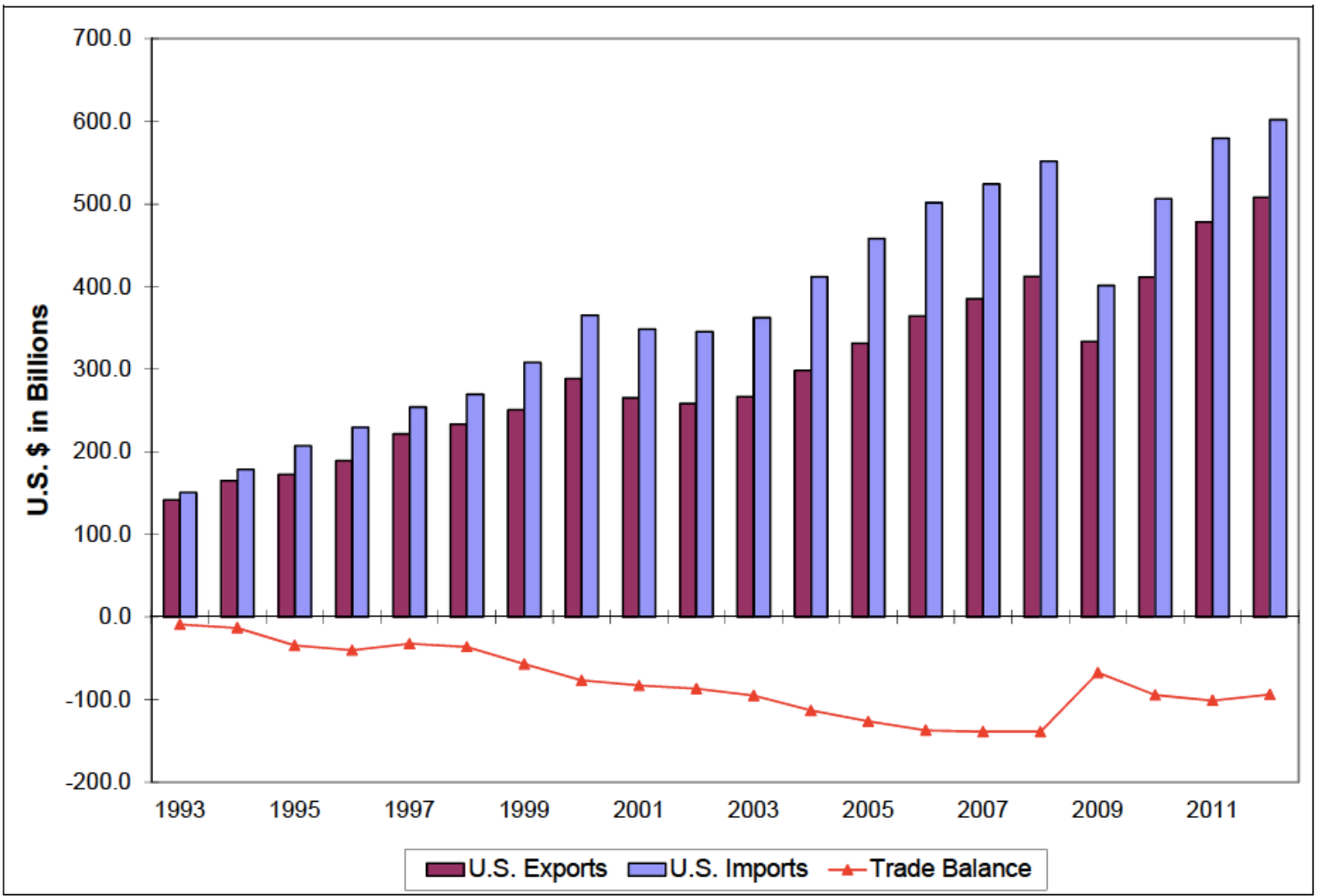

But bilateral or trilateral trade deficits are a misleading measure of economic welfare, most trade economists agree. The theory of specialization into comparative advantage that undergirds free trade holds that opening borders will allow for reallocation of resources to their most efficient and productive use, and that efficiency will grow the economic pie as a whole - so that even when the trade deficit is increasing, economic productivity and output are also increasing, and that is reflected in better welfare for us as consumers, and also in reallocation of US economic activity into other more productive domains both domestically and internationally.

By that measure, most studies of NAFTA say that the overall effect - besides the fact that clearly trade volume has gone up - in terms of how that has affected economic welfare in the US - has been rather modest but on the net positive side, albeit far less than had been expected. Although the US deficit in trade in goods has increased, at the same time economic activity has reallocated to other areas such as services. This graph [Slide 20, above] reflects only trade in merchandise in goods. When it comes to trade in services, the US has run a surplus with NAFTA countries that has also increased over this same period. And in addition to all of this activity, which is occurring on the "current account" side of the US economy, there is also the "capital account" side of the balance sheet, the capital markets, in which the US is clearly dominant.

But again this is only a partial narrative. The aggregate picture doesn't reflect the impact on specific industries. That impact was variable. In trade in goods, for example, some areas did very well US agriculture [supported by subsidies] got a big boost in trade with Mexico through NAFTA. Others experienced concentrated losses, and one of the clearest of those was the auto industry. [Slide 21, 
"NAFTA's impact on the auto trade"] Although the changes in the auto industry were well underway by the time NAFTA came along, there is no question that the reconfiguration of the auto industry into the transnational supply chain that it now is was accelerated after NAFTA, with the auto parts production in Mexico rising by $500 \%$ over the first ten years of NAFTA alone [cited elsewhere in study].

\section{NAFTA's impact on the auto trade}

Table I. U.S.Trade in Vehicles and Auto Parts: 1993 and 201 I

(billions of U.S. dollars)

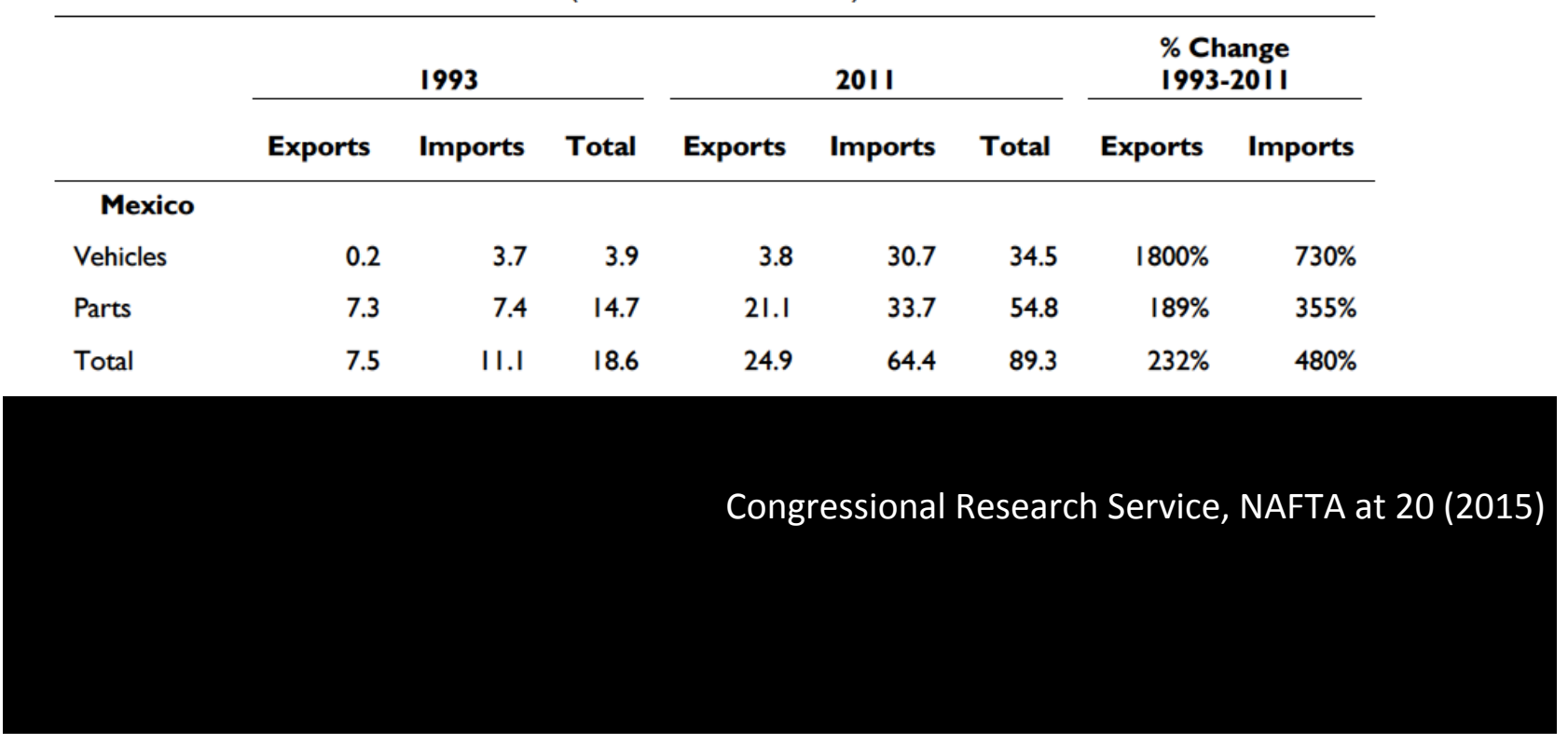

So: Problem number 1 is that even when trade generates overall economic benefits, it also creates concentrated losses. The legal and policy solution to this would be enact better assistance for trade adjustment. A program was passed into law with NAFTA but it has been widely viewed as insufficient.

Problem number 2 has to do with the types of jobs replacing those that are lost. The turn to the service economy has been accompanied by increasing income stratification. Service jobs are less protected by labor laws and labor unions, and they break into greatly separated income strata - lowincome precarious work and high income professional work.

Is this a function of trade policy? No or at least not necessarily. Consider this graph comparing manufacturing job loss across a range of countries. [Slide 22, "Not all industrialized countries have experienced the same rate of manufacturing job loss"] The US and UK experienced the highest losses (the Trump and Brexit votes are less surprising when considering this). A number of other countries also experienced significant job losses; but the point of this comparison is to highlight the relatively small losses in Germany. 


\section{Not all industrialized countries have experienced the same rate of manufacturing job loss}

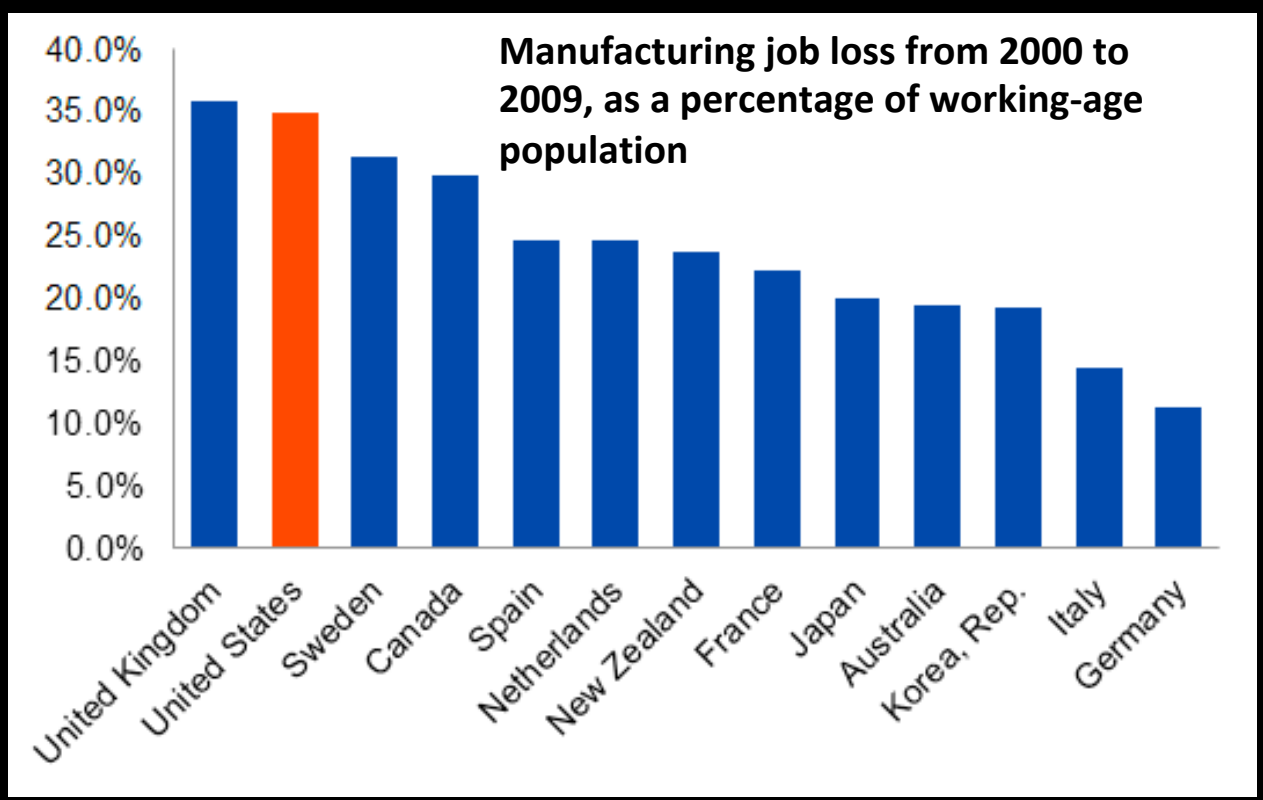

Industry Week (2014); International Comparisons of Annual Labor Force Statistics, 1970-2012

Germany has been held up as being a relative success story - one of many countries, all with robust participation in international trade, but one with many fewer losses in manufacturing jobs. Why? [Slide 23, "What, besides trade (and technology), affects global competitiveness and economic inequality?"] 


\section{What, besides trade (and technology), affects global competitiveness and economic inequality?}

- Investment in economic and social infrastructure

- Corporate and labor policy

- Policies for compensation and redistribution

One factor is heavy investment in research and development, in education and retraining.

Another factor is the different configuration of corporate and labor law and policy. Workers are more likely to have board level representation in corporate decisions in Germany. And German companies tend to be privately held, and so not subject to the kind of short-term shareholder value maximization that pressured many US and UK companies to adopt slash and burn policies in order to save their stock prices. So those capital markets in which US and UK are globally predominant are a mixed blessing because they also wind up exerting a lot of pressure on companies whose stock is traded there.

International economic law has created some specific restrictions on what governments can do in their operation of social and economic policy. For example, a number of tools to support local economic production - restrictions not only on trade but also on foreign investment and ownership - have been limited by various kinds of trade and investment agreements. But there are many remaining areas of policy space for individual countries.

Perhaps even more importantly, there is nothing in international economic law to prevent other, non-trade measures designed to support a more egalitarian economic structure. One of these would be a more redistributive tax policy that would seek to reduce and buffer losses from trade and other economic shocks. [Slide 24, "Job loss has not resulted in increased inequality in all countries"] 


\section{Job loss has not resulted in increased inequality in all countries}

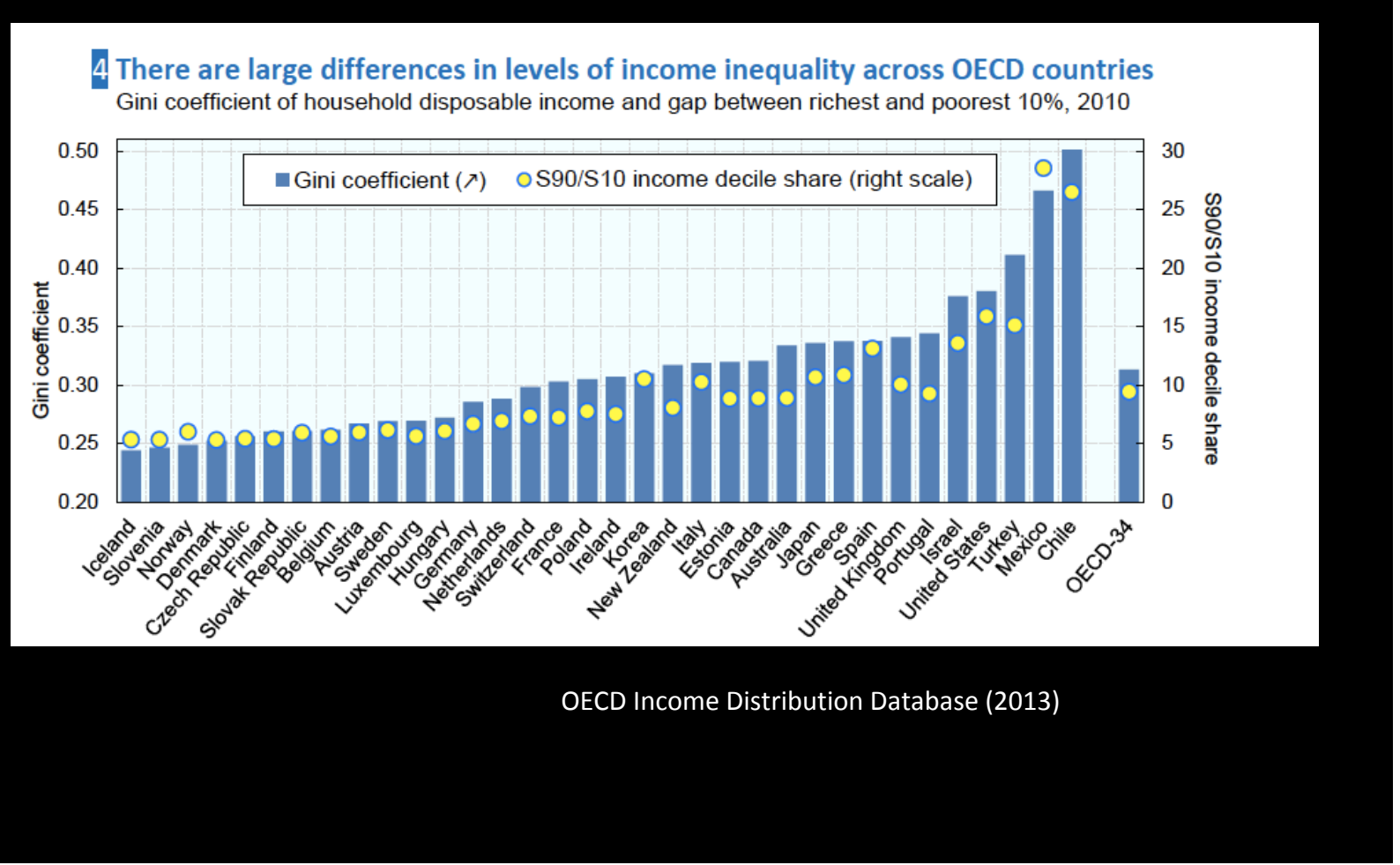

This graph shows that even those countries that did lose a relatively large amount of manufacturing, in the graph we saw earlier [Slide 22, above], like Canada and Sweden, did not see the same levels of inequality as the US and UK. This observation in turn returns us to the issues of adequate investment in infrastructure, health and education.

\section{So: What happened in Flint in terms of the decline of the economic base was connected to} international trade, but it wasn't inevitable. In response to open trade, Flint, and Michigan, and the US, could have continued to maintain a social policy of investing in and protecting workers and redistributing gains from trade liberalization. Those were domestic law and policy choices that didn't occur.

We also have to go beyond the facial content of international legal rules on the global economy, which do permit some policy space, and to interrogate the underlying and surrounding climate in which these rules are crafted.

The expansion of international trade law occurred during a period characterized by the dominance of a social theory - call it neoclassicism, neoliberalism, or market fundamentalism - that held that the state should play a minimal role. Many would argue that the international community has walked back from the extremes of the immediate post-Cold War period (such as the Washington Consensus). But I would like to suggest that we are still wrestling with the legacy of the market fundamentalist perspective, and the premise that, where a "market based solution" to a social problem can be obtained it 
is always preferable, and that solutions that require direct government intervention are always inefficient and second best.

That was the approach clearly on display in Flint, Michigan. Flint was a loser in the global economic game, so it was put into receivership by the state, and its basic public services slashed. There was no necessary relationship between international trade laws and the defunding of a local public water utility - but both arose in the same global economic and normative climate.

But: perhaps we can take the modest successes of Nairobi to heart in considering the way forward for Flint.

In order to do that, we have to be much more mindful of the role played, not only by international law, but by the ideologies that helped to shape and continue to inform it.

In addition to more radical economic neoconservatism, one can add a more moderate and much more widespread approach to legality informed by basic concepts of liberal individualism, which are more comfortable with formal rather than substantive definitions of equality.

And there are other, far less legitimate, indeed illegitimate worldviews. We have to talk about how economic ideology intersects with other ideologies, of class, gender and race. We have to ask whether we tolerate the inequities of globalization because they are disproportionately borne by those who are already marked by difference and who have historically occupied subordinate social statuses.

After all in Germany, even though it has been doing comparatively better than many of its industrialized counterparts, the political far right has still been growing, and the reaction to the global has taken ugly forms.

There remains a great deal of research to be done on the role that racial ideology has played in directly shaping global political economy. It is unfortunately most likely not incidental that Flint, Michigan, after decades of white flight, is a majority-minority city, with 57\% African American residents.

And to go back to Doha, we can draw connections in the global political economy that have been shaped by race relations. Some of those connections are historical, and so some of this work is being done by historians. Sven Beckert's Empire of Cotton provides one example. [Slide 25, "Political economy as historical legacy: Empire of Cotton"] 


\section{Political economy as historical legacy}

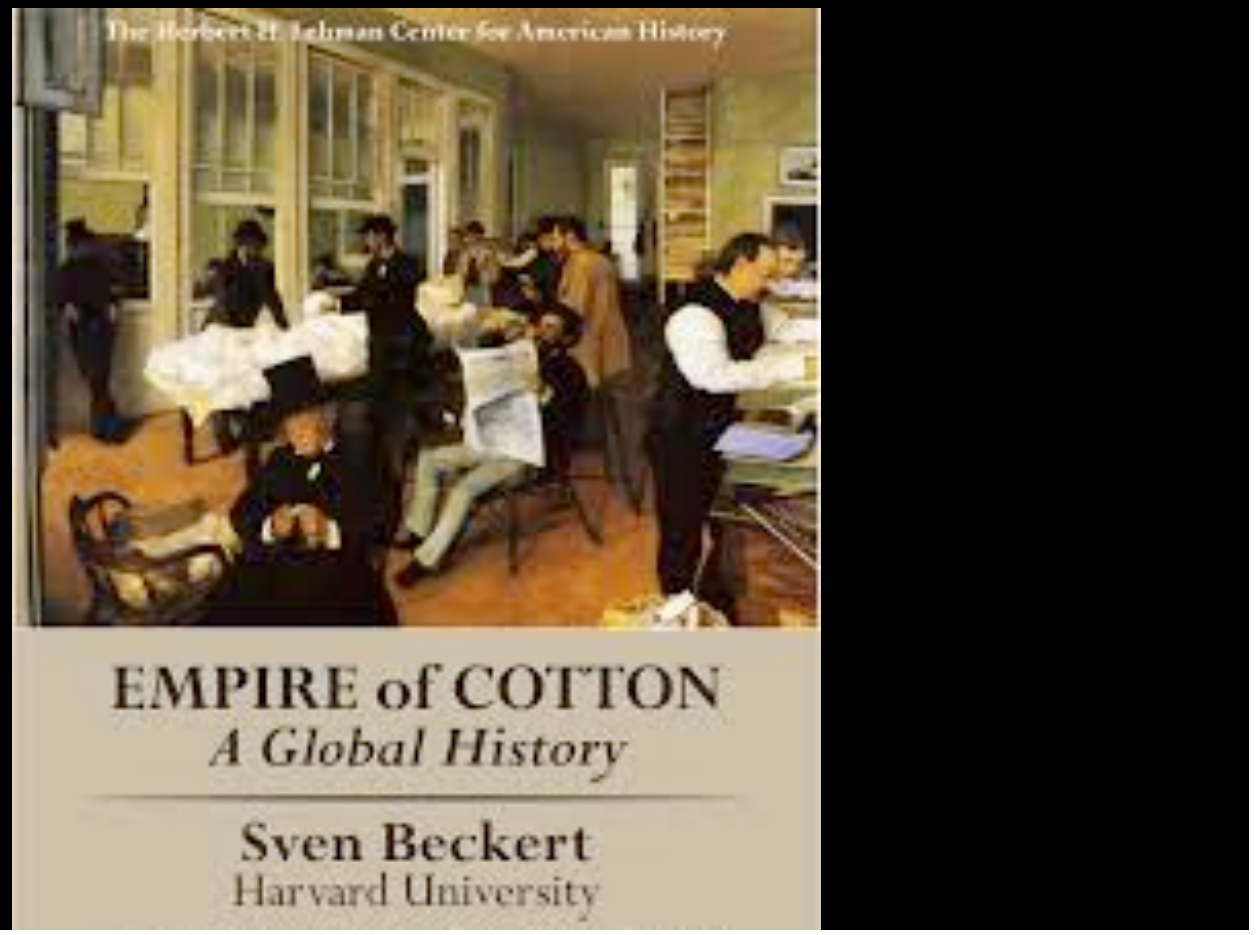

Consider the "Cotton 4" West and Central African countries mentioned earlier. Cotton production in those countries was cultivated for export initially by American and European industrialists in the $19^{\text {th }}$ century who were concerned about the drop in cotton supply for their textile mills that occurred as a result of the US Civil War. Many of the cotton-exporting economies in the global South today were cultivated by merchants in the nineteenth century desperately seeking out alternative sources of the raw material so necessary to fuel the burgeoning industrial economies of the global North.

Facing the prospect of declining cotton supplies from the US South due to the abolition of slavery and the war between the states, nineteenth century capitalists searched elsewhere for alternative supplies and in many cases actively induced cotton cultivation. ${ }^{6}$ Africa provided one such alternative. "between 1860 and 1920, 55 million acres of land in Africa, Asia and the Americas... were newly planted with cotton for world markets... Approximately 80 percent of all that new cotton-growing land was situated in territories that had not grown cotton in 1860."7

At roughly the same time that African countries were beginning to make the case against US cotton subsidies as imposing harms on them, in the Doha round, the US Department of Agriculture was facing a class action lawsuit by African-American farmers arguing that they had been excluded from those very same subsidies on racially discriminatory grounds. [Slide 26, "Political economy as historical legacy: Cotton in the United States]

\footnotetext{
${ }^{6}$ Beckert 258. This section taken from C. Thomas, “International Trade and African Heritage: The Cotton Story,” Temple Int'1 LJ, 2017.

${ }^{7}$ Beckert 358 .
} 


\section{Political economy as historical legacy}

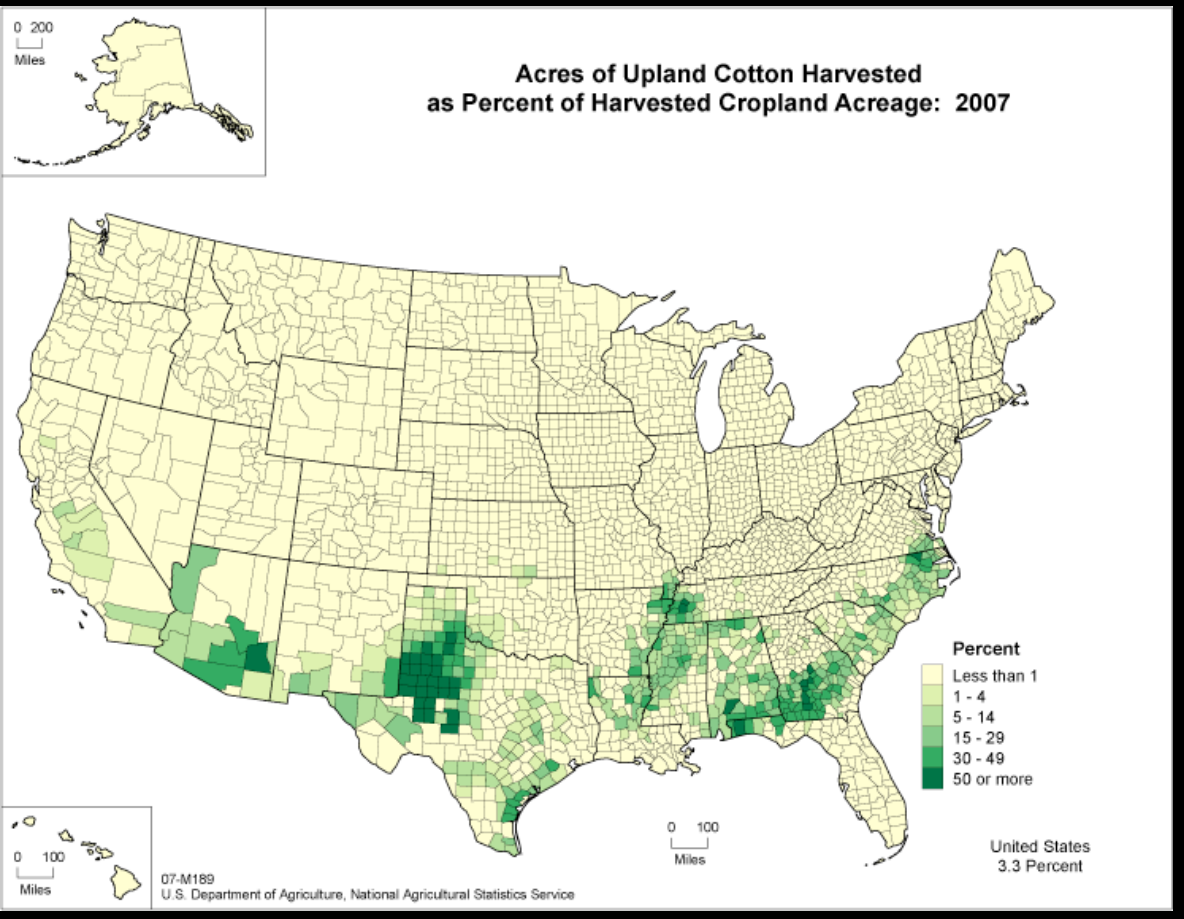

"The [U.S.

Department of

Agriculture] is

the 'last

plantation'..."

(Pigford v.

Glickman (1999)

(Judge Paul L.

Friedman))

In 1998, four hundred and one African-American farmers filed suit in U.S. federal court alleging racial discrimination by the U.S. Department of Agriculture (USDA) in its conferral of farm assistance. ${ }^{8} \mathrm{~A}$ federal court agreed, declaring the US Department of Agriculture to be the last plantation, and ordering a consent decree in favor of the plaintiffs. The court ultimately approved a consent decree enforcing a settlement agreement between African-American farmers and the USDA, finding that the USDA's "denial of credit and benefits has had a devastating impact on African American farmers." According to the Census of Agriculture, the number of African American farmers has declined from 925,000 in 1920 to approximately 18,000 in 1992.

Judge Friedman wrote, "It is difficult to resist the impulse to try to undo all the broken promises and years of discrimination that have led to the precipitous decline in the number of African American farmers in the United States. .... [The] Court finds that [this] settlement is ...a good first step."

The Pigford v. Glickman settlement, like the Doha and Nairobi WTO talks, was flawed and far from complete, but it was a step.

And we need to take more of those steps. In looking at the hierarchies of the global economy, we have to question to what extent we have absorbed a perspective that sees these hierarchies as natural

\footnotetext{
${ }^{8}$ Pigford v. Glickman, 182 F.R.D. 381, 382-383 (1998).
} 
and perhaps even inevitable; that rationalizes the contradictions between the implied outcomes of a liberalized international economy and the economic realities facing the poor, whether in our own country or elsewhere; and that fails to see the opportunities for reimagination in social and economic policy and law.

So to conclude: we have inherited a global economy shaped by international legal rules but also interpretive ideologies, social biases and habits of mind. --

-- Those rules and practices have helped to create a world of incredible prosperity, but also of inequality and instability. --

-- The challenge is daunting but clear: our task is to see law not as static, but as dynamically capable of moving towards greater economic and social development and justice for present and future generations or what was once called a "New International Economic Order." 